"Does Governance Explain Unofficial Activity?”

by

James W. May, William H. Pyle and Paul M. Sommers

June, 2002

MIDDLEBURY COLLEGE ECONOMICS DISCUSSION PAPER NO. 02-01

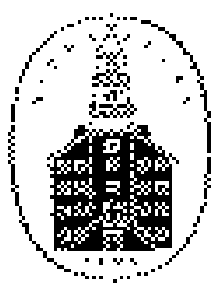

DEPARTMENT OF ECONOMICS

MIDDLEBURY COLLEGE

MIDDLEBURY, VERMONT 05753

http://www.middlebury.edu/ econ 


\title{
Does Governance Explain Unofficial Activity?
}

by

\author{
James W. May \\ William H. Pyle \\ Paul M. Sommers
}

Department of Economics

Middlebury College

Middlebury, Vermont 05753

JEL \#: O17, P26 


\section{Does Governance Explain Unofficial Activity?}

A proliferation of indices on tax rates, measures of regulation, the legal environment, and corruption with widely differing scales have been used by Johnson et al. (1998) and Friedman et al. (2000), among others, to explain differences in unofficial activity across a sample of between 32 and 69 countries. Recently, the World Bank released a new database containing over 300 governance indicators compiled from a variety of sources. Kaufmann et al. (1999) organized a subset of these governance indicators into six "clusters" or more broadly defined categories. In a cross-section of the same 69 countries examined by Friedman et al. (2000), we provide new empirical evidence of the importance of governance to unofficial activity in non-transition economies (notably, OECD countries). Surprisingly, the association between better governance and less unofficial activity is weak in transition economies and weaker still in Latin American countries.

Estimates of the share of the unofficial economy of 69 countries (18 of which are transition or post-communist countries in Eastern Europe and the former Soviet Union) are from Friedman et al. (2000; Table 1, base estimate (share 1), pp. 466-468). All six aggregate governance indicators (at www.worldbank.org/research/growth) discussed below are measured on the same scale, from -2.5 to +2.5 . The measure is higher (that is, closer to +2.5 ) in economies that discourage unofficial activity. Thus one would expect an inverse

relationship between any one of the six governance indicators and the share of the unofficial economy as a percentage of GDP. 
The first of the six governance indicators used as an independent variable is "Voice and Accountability". This measure is higher for countries that hold those in authority accountable for their actions. The higher the measure, the more widespread are civil liberties and political rights. "Political Instability and Violence" measures the perceived likelihood of unconstitutional or violent changes in government. These first two clusters therefore summarize key aspects of the process by which those in authority are selected and replaced.

"Government Effectiveness" is a catchall variable for the quality of public services, the competence of civil servants, and the independence of the civil service from political pressure. "Regulatory Burden" measures the incidence of policies that are not perceived as business-friendly, such as price controls and inadequate bank supervision. These two clusters capture the capacity of the nation-state to produce and implement sound public policies.

"Rule of Law" seeks to measure the extent to which the public has confidence in and abides by the rules of society. Enforceable contracts and a strong judiciary form the basis for market-friendly interactions. "Graft" measures the public's perception of corruption, that is, the exercise of public power for private gain. These last two clusters capture the respect of citizens for the rules which govern their interactions.

The averages for transition economies and non-transition economies for each of the six governance indicators are reported in Table 1. The differences between the two groups of countries are greatest for "Government Effectiveness" and "Graft". For "Political Instability", the differences are significant at only the 10 percent level. 
Strong differences emerge between transition and non-transition economies when the unofficial economy as a percentage of GDP is regressed on each of the six governance indicators, one at a time. The regression results in Table 2 underscore the importance of governance indicators as determinants of unofficial activity in non-transition economies alone. A one-point increase in the "Regulatory Burden" index, for example, is associated with a dramatic 31.6 percent decrease in the share of the unofficial economy of nontransition economies. (Recall that increases in any one of the governance indices are business-friendly and hence discourage movement "underground".) The same one-point increase in the "Regulatory Burden" index is associated with a much smaller (7.8 percent) decrease in the share of the unofficial economy of transition economies. "Political Instability" and "Graft" alone are significant at explaining variation in the relative size of the unofficial economy of governments in transition.

The regional regression results in Table 3 show that the significant results earlier reported for non-transition economies largely depend on the presence of OECD countries in our sample. Governance does not appear to matter for Latin American countries. The remaining sixteen countries in the sample of 51 non-transition economies include eight Asian countries, four from the Middle East or North Africa, and four from Sub-Saharan Africa. All three other groups are thus too small to provide meaningful regional comparisons.

In summary, the relationship between share of the unofficial economy in nontransition economies and governance is strong for each of the six basic governance concepts. However, governance, as measured by these indicators, matters little for transition economies, save for "Graft" and "Political Instability". 


\section{Concluding Remarks}

The cross-country results presented here show that most aspects of governance affect transition and non-transition economies differently. For governments in transition, more regulation, greater voice and accountability, heightened government effectiveness, and stronger rule of law surprisingly matter very little. What matters most for these transition economies is political stability (that is, the ability of citizens to peacefully select and replace those in power) and insulating the country's business environment from corruption. 


\section{Table 1. Six Aggregate Governance Indicators, Transition and Non-Transition Economies}

\begin{tabular}{|c|c|c|c|c|c|c|c|}
\hline \multirow{2}{*}{$\begin{array}{l}\text { Governance } \\
\text { Indicator }\end{array}$} & \multicolumn{3}{|c|}{$\begin{array}{l}\text { Transition } \\
\text { Economies } \\
\quad(n=18)\end{array}$} & \multicolumn{3}{|c|}{$\begin{array}{l}\text { Non-Transition } \\
\text { Economies } \\
(\mathrm{n}=51)\end{array}$} & \multirow{2}{*}{$\begin{array}{c}\mathrm{p} \text {-value } \\
\text { on } \\
\text { difference } \\
\text { between } \\
\text { averages }\end{array}$} \\
\hline & $\min$ & $\max$ & average & $\min$ & $\max$ & average & \\
\hline $\begin{array}{c}\text { Voice and } \\
\text { Accountability }\end{array}$ & $\begin{array}{c}\text { Uzbekistan } \\
(-1.343)\end{array}$ & $\begin{array}{c}\text { Czech Rep } \\
(1.201)\end{array}$ & .174 & $\begin{array}{l}\text { Nigeria } \\
(-1.234)\end{array}$ & $\begin{array}{c}\text { Switzerland } \\
(1.694)\end{array}$ & .685 & .022 \\
\hline $\begin{array}{l}\text { Political } \\
\text { Instability }\end{array}$ & $\begin{array}{l}\text { Georgia } \\
(-0.761)\end{array}$ & $\begin{array}{l}\text { Hungary } \\
(1.245)\end{array}$ & .181 & $\begin{array}{c}\text { Sri Lanka } \\
(-1.628)\end{array}$ & $\begin{array}{l}\text { Switzerland } \\
(1.690)\end{array}$ & .478 & .10 \\
\hline $\begin{array}{l}\text { Government } \\
\text { Effectiveness }\end{array}$ & $\begin{array}{c}\text { Uzbekistan } \\
(-1.305)\end{array}$ & $\begin{array}{l}\text { Poland } \\
(0.674)\end{array}$ & -.279 & $\begin{array}{l}\text { Nigeria } \\
(-1.321)\end{array}$ & $\begin{array}{c}\text { Singapore } \\
(2.082)\end{array}$ & .633 & $<.0001$ \\
\hline $\begin{array}{c}\text { Regulatory } \\
\text { Burden }\end{array}$ & $\begin{array}{l}\text { Belarus } \\
(-1.466)\end{array}$ & $\begin{array}{l}\text { Hungary } \\
(0.854)\end{array}$ & -.109 & $\begin{array}{l}\text { Nigeria } \\
(-0.352)\end{array}$ & $\begin{array}{c}\text { Singapore } \\
(1.245)\end{array}$ & .659 & .0004 \\
\hline $\begin{array}{l}\text { Rule } \\
\text { of Law }\end{array}$ & $\begin{array}{l}\text { Belarus } \\
(-0.876)\end{array}$ & $\begin{array}{l}\text { Hungary } \\
(0.706)\end{array}$ & -.121 & $\begin{array}{c}\text { Guatemala } \\
(-1.106)\end{array}$ & $\begin{array}{c}\text { Switzerland } \\
(1.996)\end{array}$ & .640 & .0001 \\
\hline Graft & $\begin{array}{l}\text { Azerbaijan } \\
(-0.998)\end{array}$ & $\begin{array}{l}\text { Hungary } \\
(0.614)\end{array}$ & -.318 & $\begin{array}{l}\text { Paraguay } \\
(-0.958)\end{array}$ & $\begin{array}{c}\text { Denmark } \\
(2.129)\end{array}$ & .620 & $<.0001$ \\
\hline
\end{tabular}




\section{Table 2. Regressions of Unofficial Economy (as \% of GDP) on Governance Indicators, Transition and Non-Transition Economies}

\begin{tabular}{|c|c|c|c|c|c|c|}
\hline \multirow{2}{*}{$\begin{array}{c}\text { Governance } \\
\text { Indicator }\end{array}$} & \multicolumn{3}{|c|}{ Transition Economies } & \multicolumn{3}{|c|}{ Non-Transition Economies } \\
\hline & Constant & Slope & $R^{2}$ & Constant & Slope & $R^{2}$ \\
\hline $\begin{array}{c}\text { Voice and } \\
\text { Accountability }\end{array}$ & $\begin{array}{l}30.03 \\
(7.46) * *\end{array}$ & $\begin{array}{c}-7.92 \\
(-1.50)\end{array}$ & .123 & $\begin{array}{l}40.04 \\
(16.86)^{* *}\end{array}$ & $\begin{array}{l}-17.44 \\
(-7.70) * *\end{array}$ & .548 \\
\hline $\begin{array}{l}\text { Political } \\
\text { Instability }\end{array}$ & $\begin{array}{l}31.69 \\
(8.68) * *\end{array}$ & $\begin{array}{l}-16.74 \\
(-2.69) *\end{array}$ & .312 & $\begin{array}{l}35.97 \\
(16.23)^{* *}\end{array}$ & $\begin{array}{l}-16.51 \\
(-6.93) * *\end{array}$ & .495 \\
\hline $\begin{array}{l}\text { Government } \\
\text { Effectiveness }\end{array}$ & $\begin{array}{l}25.45 \\
(5.97) * *\end{array}$ & $\begin{array}{l}-11.49 \\
(-1.73)\end{array}$ & .157 & $\begin{array}{l}38.39 \\
(17.70)^{* *}\end{array}$ & $\begin{array}{l}-16.28 \\
(-8.07) * *\end{array}$ & .570 \\
\hline $\begin{array}{c}\text { Regulatory } \\
\text { Burden }\end{array}$ & $\begin{array}{l}27.80 \\
(6.95)^{* *}\end{array}$ & $\begin{array}{c}-7.78 \\
(-1.39)\end{array}$ & .108 & $\begin{array}{l}48.94 \\
(11.26)^{* *}\end{array}$ & $\begin{array}{l}-31.64 \\
(-5.48) * *\end{array}$ & .380 \\
\hline $\begin{array}{l}\text { Rule } \\
\text { of Law }\end{array}$ & $\begin{array}{l}26.97 \\
(6.93) * *\end{array}$ & $\begin{array}{l}-13.98 \\
(-1.88)\end{array}$ & .180 & $\begin{array}{l}38.24 \\
(17.95)^{* *}\end{array}$ & $\begin{array}{l}-15.87 \\
(-8.21) * *\end{array}$ & .579 \\
\hline Graft & $\begin{array}{l}23.17 \\
(5.68) * *\end{array}$ & $\begin{array}{l}-17.25 \\
(-2.62) *\end{array}$ & .300 & $\begin{array}{l}36.99 \\
(18.25)^{* *}\end{array}$ & $\begin{array}{l}-14.45 \\
(-8.32) * *\end{array}$ & .586 \\
\hline
\end{tabular}

Note: Numbers in parentheses are $t$-statistics.

$*$ Denotes significant at $5 \%$ level.

**Denotes significant at $1 \%$ level. 
Table 3. Regressions of Unofficial Economy (as \% of GDP) on Governance Indicators, OECD and Latin American Countries

\begin{tabular}{|c|c|c|c|c|c|c|}
\hline \multirow{2}{*}{$\begin{array}{l}\text { Governance } \\
\text { Indicator }\end{array}$} & \multicolumn{3}{|c|}{$\operatorname{OECD}(\mathrm{n}=20)$} & \multicolumn{3}{|c|}{ Latin America $(\mathrm{n}=15)$} \\
\hline & Constant & Slope & $R^{2}$ & Constant & Slope & $R^{2}$ \\
\hline $\begin{array}{c}\text { Voice and } \\
\text { Accountability }\end{array}$ & $\begin{array}{l}41.43 \\
(5.24) * *\end{array}$ & $\begin{array}{l}-19.72 \\
(-3.66)^{* * *}\end{array}$ & .426 & $\begin{array}{l}39.74 \\
(9.47) * *\end{array}$ & $\begin{array}{l}-7.80 \\
(-1.07)\end{array}$ & .082 \\
\hline $\begin{array}{l}\text { Political } \\
\text { Instability }\end{array}$ & $\begin{array}{l}22.93 \\
(8.04)^{* * *}\end{array}$ & $\begin{array}{l}-9.16 \\
(-3.80)^{* * *}\end{array}$ & .445 & $\begin{array}{l}36.60 \\
(9.02)^{* *}\end{array}$ & $\begin{array}{l}-8.03 \\
(-1.13)\end{array}$ & .090 \\
\hline $\begin{array}{l}\text { Government } \\
\text { Effectiveness }\end{array}$ & $\begin{array}{l}26.91 \\
(8.08) * *\end{array}$ & $\begin{array}{l}-9.99 \\
(-4.42)^{* *}\end{array}$ & .521 & $\begin{array}{l}37.57 \\
(9.57)^{* *}\end{array}$ & $\begin{array}{c}-6.86 \\
(-0.99)\end{array}$ & .070 \\
\hline $\begin{array}{l}\text { Regulatory } \\
\text { Burden }\end{array}$ & $\begin{array}{l}28.62 \\
(4.89)^{* * *}\end{array}$ & $\begin{array}{l}-17.29 \\
(-2.76) *\end{array}$ & .298 & $\begin{array}{l}35.02 \\
(4.30)^{* *}\end{array}$ & $\begin{array}{c}5.35 \\
(0.42)\end{array}$ & .014 \\
\hline $\begin{array}{l}\text { Rule } \\
\text { of Law }\end{array}$ & $\begin{array}{l}28.48 \\
(11.59)^{* * *}\end{array}$ & $\begin{array}{l}-11.47 \\
(-6.68) * *\end{array}$ & .713 & $\begin{array}{l}34.34 \\
(8.58) * *\end{array}$ & $\begin{array}{c}-12.00 \\
(-1.98)\end{array}$ & .232 \\
\hline Graft & $\begin{array}{l}23.32 \\
(6.00) * *\end{array}$ & $\begin{array}{l}-6.78 \\
(-2.84) *\end{array}$ & .309 & $\begin{array}{l}35.34 \\
(8.37) * *\end{array}$ & $\begin{array}{l}-9.33 \\
(-1.41)\end{array}$ & .132 \\
\hline
\end{tabular}

Note: Numbers in parentheses are $t$-statistics.

*Denotes significant at 5\% level.

**Denotes significant at $1 \%$ level. 


\section{References}

Friedman, E., Johnson, S., Kaufmann, D., and Zoido-Lobaton, P., 2000. Dodging the grabbing hand: the determinants of unofficial activity in 69 countries. Journal of Public Economics 76, 459-493.

Johnson, S., Kaufmann, D., and Zoido-Lobaton, P., 1998. Regulatory discretion and the unofficial economy. American Economic Review 88, 387-392.

Kaufmann, D., Kraay, A., and Zoido-Lobaton, P., 1999. Governance matters. The World Bank, unpublished manuscript. 